\title{
Astringency of Musa AAB 'Rastali' fruit is affected by tannin content
}

\begin{abstract}
Fruit of Musa AAB ' Rastali' has a special and unique astringent taste as compared to other local cultivars of banana. The astringency is caused by tannin. To minimize the unpleasant taste, this banana is usually consumed when senescence spots appeared. A study was conducted to understand the tannin content of 'Rastali' banana fruit and its microstructure during growth and development. Fruit development stages were dated at every two week intervals beginning of the first week until the 12th week after emergence of the first hand. Hands were numbered from the top of the bunch to the bottom (hand one, basal fruit at the top; and hand six, distal hand at the bottom), and only six hands of bananas were used in this study. The experiment was repeated thrice. The tannin content of ' Rastali' banana decreased as fruit matured. Hands which emerged first contained lower tannin content than other hands. Under light microscopy, three different types of tanniferous cells were found in ' Rastali' banana. These tanniferous cells were found in peel, peel-pulp transition and pulp regions of fruit during growth and development. However, tanniferous cells became less obvious as fruit matured in all regions of fruit. The decrease of tannin content was supported by microstructural study.
\end{abstract}

Keyword: Growth and development; Microstructure; Senescence spot; Tanniferous cell 